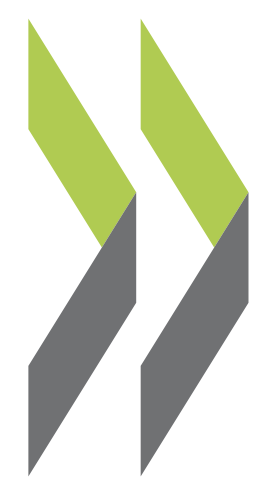

PEB Exchange, Programme on Educational Building 2002/05

The Australian Science and Mathematics School, Flinders University, South Australia
OECD

https://dx.doi.org/10.1787/743056378420 


\section{THE AUSTRALIAN SCIENCE AND MATHEMATICS SCHOOL, FLINDERS UNIVERSITY, SOUTH AUSTRALIA}

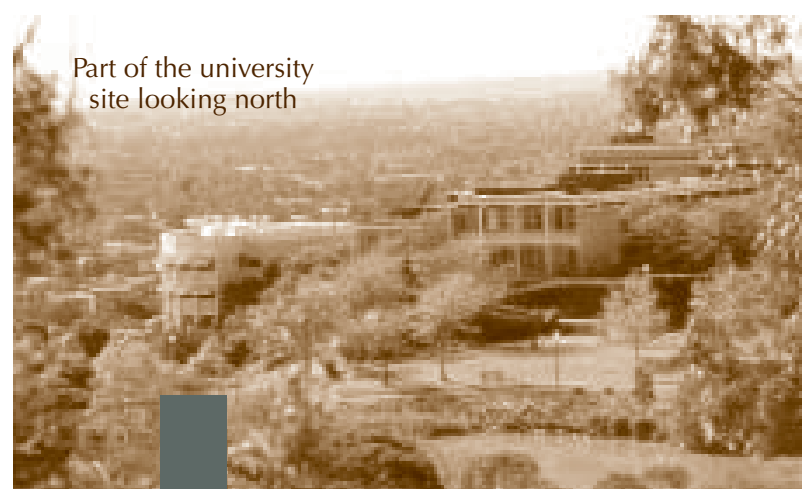

\section{Introduction}

The South Australian Department of Education, Training and Employment, in association with Flinders University, are collaborating in the design, construction and development of a senior secondary high school which will specialise in the teaching of mathematics and science and focus on innovative pedagogies.

The Australian Science and Mathematics School (ASMS) will accommodate 450 students, with up to 150 from overseas, in years 10, 11 and 12 and will be open from 8.00 a.m. to 8.00 p.m. on most days of the year including school holidays. In conjunction with the Science Faculty of Flinders University, the school will offer adult learning approaches for these final three years of schooling at the pre-tertiary level and will collaborate in the development of curriculums based on the "new sciences" such as nano-technology.

The school is expected to provide leadership to the State of South Australia as well as to the nation in re-energising the teaching of maths and science. The school's director, Ron Lake, describes the ASMS as being "designed to prepare students to shape our world, our future, our global community and our environment through the great changes of science and technology now moving to centre stage in the new century." The development of staff in the existing schools throughout the state and across Australia will occur through teachers visiting the complex to experience new approaches to pedagogy or through the outreach and online programmes developed by the school.

Over the three years as the students advance through the school, they will increasingly encounter its adult, selfdirected, constructivist, problem-based and independent learning approaches, and it is hoped that upon graduation they will be eager to continue with maths and science and be sufficiently proficient to perform at high levels in tertiary study or in the workforce.

\section{The project}

The joint venture partners believe that no school such as this one exists. Their vision is to completely rethink the schooling, educational, teaching and learning processes such that the facility will not even look like a school.

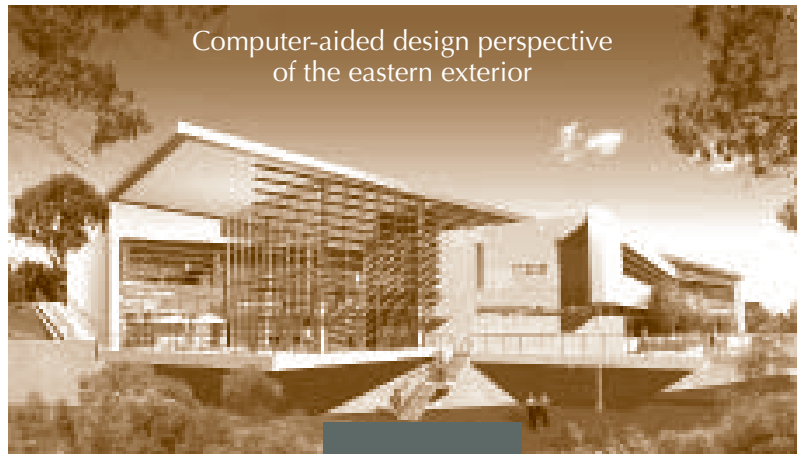

The proposed new building, adjacent and connected to the faculties of education and science at Flinders University, will facilitate teaching and learning of mathematics and science in a research environment where teachers will engage in staff development, where research will be carried out into new technology-enhanced pedagogies and where science faculty staff will foster in students a willingness to pursue learning and careers in science and mathematics.

The facility briefing process included extensive international research into best practices with study visits to eight of the leading science and mathematics schools in Europe and the United States. Four working parties to aid the briefing process were established, including staff development, facilities development, curriculum development and information technology strategy.

\section{The environmental response}

The project manager for the ASMS, Peter Sachs, a specialist in technology-enhanced teaching and learning, notes that "the ASMS building and environs are designed to specifically use space and place as a learning tool. The building has a range of environmental features 
such as scientifically advanced building materials and structures, a mixed mode of air-conditioning which automatically responds to both internal and external environments in transferring heat loads throughout the building, energy efficient lighting systems, environmentally friendly and efficient materials in the structure of the building, water reuse facilities and passive measures such as building orientation for local climatic conditions." The building management system of the ASMS will be connected to the school computer network so students can measure the performance of the building.

The school grounds and gardens, or "outdoor classrooms", are designed to illustrate Australian native environmental conditions, and can be accessed through "break out" areas from the learning commons offering opportunities for students to monitor flora and fauna activities.

\section{Learning commons, learning studios and other facilities}

A key feature of the school is the break away from the traditional concepts of classrooms and laboratories. These have been replaced by such concepts as "learning commons" and "learning studios".

The spaces are designed to be student centred, rather than teacher centred, and will foster collaborative syndicate and project-based learning. Each student will have his or her own "home-base" work station located in one of the learning commons. Students may flexibly organise their home-bases to meet social or study group needs. Students will move around the school, the university campus and the local community, spending significant amounts of time in each, but will always be able to identify with their home-base in the school. Eight specialist learning studios cater for the eight learning areas in the South Australian Curriculum, Standards and Accountability Framework; the studios will take a group

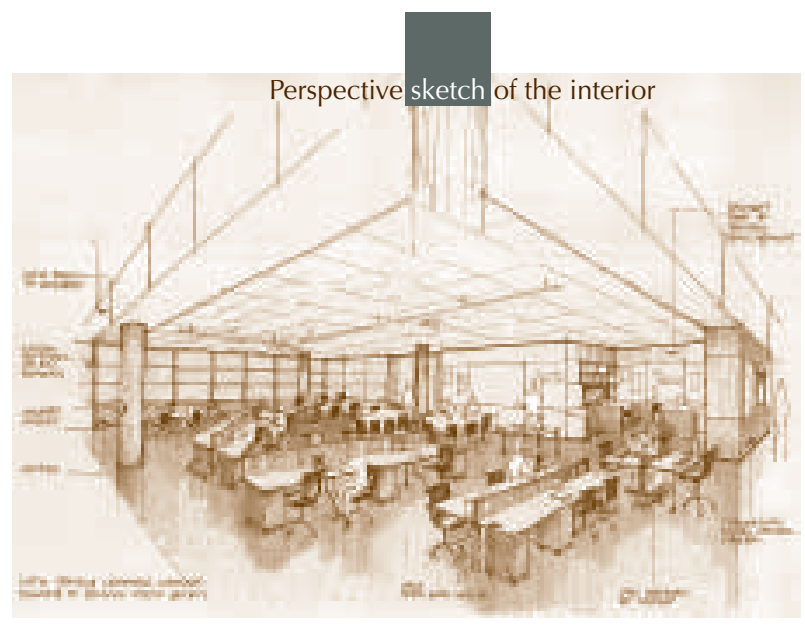

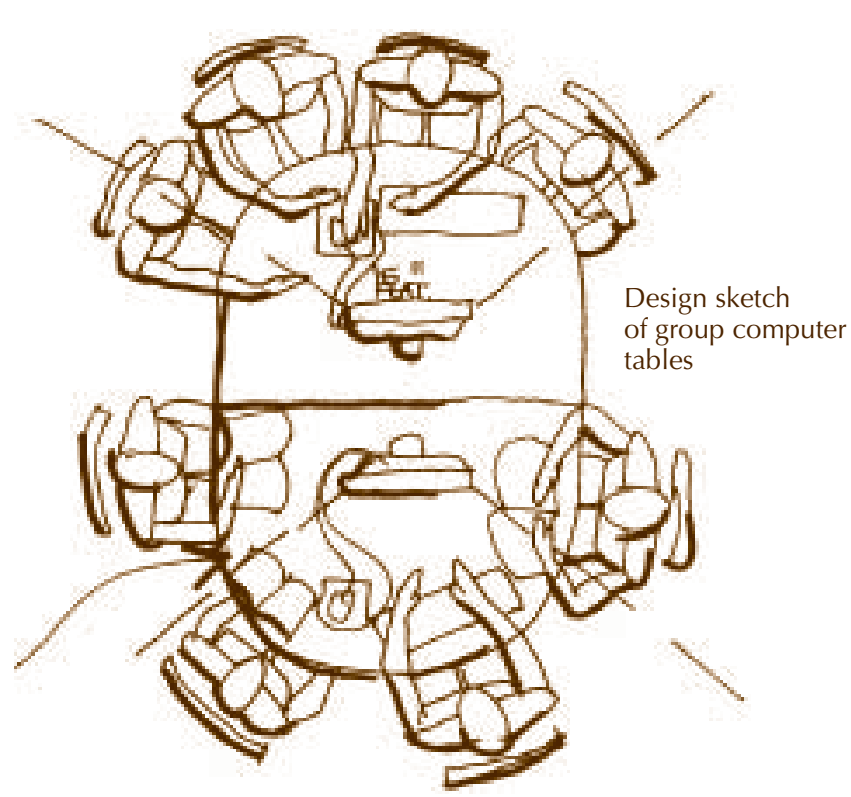

of students working on project-based activities rather than the traditional class-based cohort in laboratories. Special furniture has been designed to meet the flexible nature of these spaces.

Students will be able to work individually, in small groups or in class groups, or will be able to meet as a whole-year or complete school group in a range of purpose-designed facilities ranging from their home-base to lecture theatres and laboratories within the university. The school design deliberately incorporates large central common spaces for circulation, break out areas from learning commons and studios for formal and informal learning, displays, exhibitions, assemblies and conferences.

In addition, there are seminar rooms, meeting rooms, staff preparation rooms, student and staff social areas, and central common spaces. Zones are allocated for visiting teachers to collaborate and observe the school's innovative approaches to science and maths teaching, learning and research. Academic staff from the university faculties of science and education will also collaborate in these staff development exercises.

\section{A day in the life of ASMS students}

Louise Mather, curriculum project officer for the ASMS, has described how students might spend the day at the school. A typical day might start with a literature forum with students from local high schools. Then, with students from more distant high schools, the ASMS students might join a video conference class on economics. The students might then send via Internet updated information on the experiment they are running to vulcanologists working on a live volcano in Hawaii. They might participate in a working lunch with a visiting archaeologist from the South Australian Museum. They might work with a local business to develop and program a microchip for a robotic drama production or join the mobile phone radiation research group at Flinders University Science Labs. Some might 
leave the ASMS to attend their part-time role as explainers at the Investigator Science Centre for a year 5 class on forces. On the weekend students might access the online archive lecture series on biotechnology held at Flinders University during the week.

\section{Achieving the vision}

The school will open in January 2003. Preparation for initial staff appointments is underway, the curriculum is being developed and staff development programmes are being planned. Teaching in a student-centred environment in a building with no traditional classrooms or laboratories will be a challenge, and staff development is seen as a critical part of the success of the school. The staff will be trained in how to use the building as a "learning tool", in much the same way as they are already trained in the use of information and communications technology. Staff will be expected to contribute to the ongoing professional development charter of the school.

Further information about the school is available from: Kenn Fisher, Partner, Educational Planning and Design, Woods Bagot, e-mail: kenn.fisher@woodsbagot.com.au

Ron Lake, ASMS Director, e-mail:

lake.ron@saugov.sa.gov.au

Peter Sachs, ASMS Project Director, e-mail:

sachs.peter@saugov.sa.gov.au

ASMS Web site: www.asms.sa.edu.au

\section{THE LYCÉE MAXIMILIEN PERRET IN FRANCE}

The new premises of the Lycée Maximilien Perret, an upper secondary and continuing education institution, meets many - but, as experience has shown, not all of its users' needs. Why was it necessary to relocate the lycée in the first place? Which aspects of the new buildings effectively meet users' needs, and which facilities have not lived up to expectations? This article will examine these questions in the spirit of postoccupancy evaluation.

The Maximilan Perret school, familiarly known as "Max' $\mathrm{P}$ ", combines programmes of initial education within the secondary school system, alternating in-school/enterprise-based training and continuing education for adults (Groupement d'Établissements de Formations à l'Énergie, G.E.F.En, providing training in

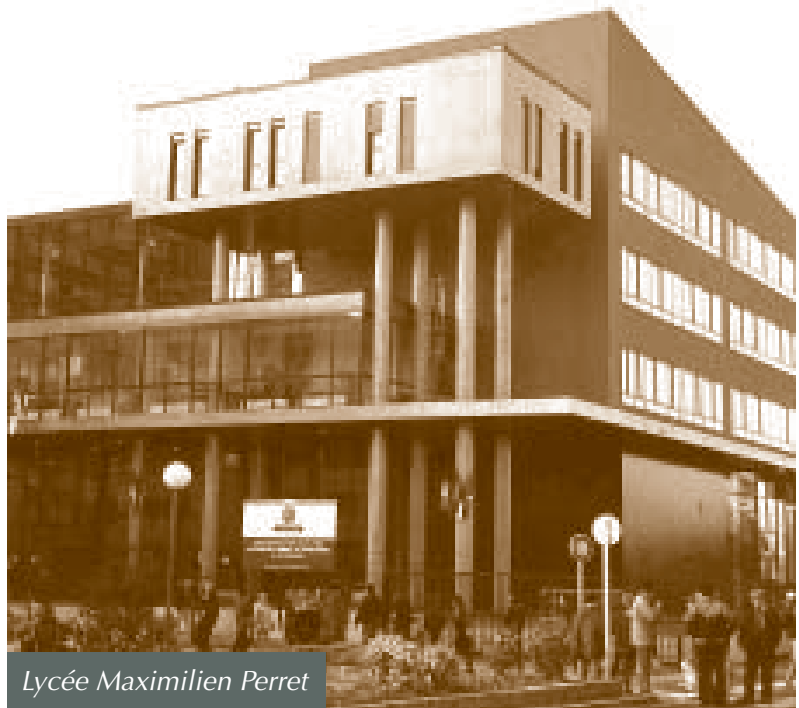

energy-related fields). ${ }^{1}$ The lycée provides technical training in jobs ranging from skilled worker to engineer, with specialisation in air-conditioning and sanitation, environmental protection, building management, etc.

The lycée was originally created as a vocational training school in 1887 to meet the need for skilled workers in plumbing and roofing, and later evolved in response to industrial needs and institutional changes. The lycée had outgrown the old house in Vincennes, a town on the outskirts of Paris, where it had been located since 1953: outbuildings had been transformed into classrooms, courtyards were occupied by prefabricated buildings and basements were filled with workshops and technical facilities.

New premises were built in the town of Alfortville, a few kilometres outside Paris, and were inaugurated in May 2000. The total cost was EUR 55 million, of which EUR 9 million were for technical training facilities (in the fields of sanitation and heating, refrigeration, air conditioning, etc.). Nearly all of the staff, strongly attached to the Vincennes site, were opposed to building the new school. The educational programme was modified at the time of the move with the introduction of general streams. However, the staff of "Max'P" were able to participate in the design of the school and the monitoring of its construction. The construction of the building was dissociated from the new pedagogical infrastructure which led to difficulties - since the administration wanted partner enterprises (which were often owned by former pupils) to participate in building the school; according to former principal Claude Gyral, these graduates of the school "really put their heart into building a fine project".

The lycée moved to its new premises in 1997, the year of its $110^{\text {th }}$ anniversary. The architect, Massimiliano Fuksas, described the new site as follows: "This architecture is

1. The G.E.F.En has developed partnerships with educational institutions and enterprises in Portugal, Spain, China, Tunisia and Gabon. 